\title{
RIGHT TO SAFETY AND SECURITY FOR PASSENGERS TRAVELING BY THE PUBLIC ROAD TRANSPORTATION
}

\author{
Maria Madalina; Kukuh Tejomurti; Winarno Budyatmojo \\ Faculty of Law, University of Sebelas Maret \\ Email: maria.madalina@staff.uns.ac.id; kukuhfhuns@gmail.com
}

\begin{abstract}
This article aimed to observe the safety protection of public road transportation and some public areas in Yogyakarta and Surakarta. The Road and urban public transport terminals, station, and transshipment centres were mainly established at the meeting points of different traffic lines. If we compare the terror-threat against infrastructure, building, and vehicles, then we can see that much more terrorist attacks were directed against the vehicles, than against bridges or tunnels. Safety protection on public road transportation and its public areas is one of the efforts to enforce right to life and right to sustain life in line with article 28A of Indonesian Constitution of 1945. This issue is important to be observed because two cities are prone to be attacked by terrorist and sometimes passengers or visitors are not responsive to disasters as long as they are on public road transportation and public areas. This article have two important problem to be observed, first problem is how already passengers or visitors of public road transportation and its public areas understand safety procedures of those areas?; second problem is how policy of safety protection need to be enforced on two public road transportation and public areas in order to protect right to life safely of passengers? The normative and empirical legal research is used to this research by using interviews and field observation. The result of this research concisely state that at this time the bus station and rail station is still not implemented maximum safety and security procedures to passengers and passengers or visitors do not understand about safety procedures and are not responsive to dangerous circumtances surrounded them. Maximum safety protection is important to prevent terrorism crime, narcoticss crime, and prevent any casualties due disasters. Security officers should check the condition of bags and luggage of passengers or visitors in order to prevent any threats there. Safety briefing is also implemented to keep a passengers concer.
\end{abstract}

Keywords: safety procedure, right to life, public area

\section{A. INTRODUCTION}

Indonesia is one of the largest countries in the world without a decent or wellfunctioning public transportation system. The public transportation issue itself is not only limited to large cities such as Jakarta, Surabaya or Medan, but it also involves many intracity transportation hubs and island transportation systems. It is, without a doubt, one of the largest and most complex issues that the government and private sector must tackle from all fronts. 
At the 1960s, our then-president, Sukarno, ordered the removal of the tram-train system and replaced it with buses, disregarding the possibility of a rapid increase in public transportation demand in the future. the last decade, the average number of public transportation users has decreased rapidly, partly due to the overall growth of the Indonesian economy, which has increased the number of middle-income earners and the market's vehicle affordability.

Ten years ago, public transport users accounted for 45 percent of total transportation users, and it remained so until 2012. From that point, motorcycles became more ubiquitous as a result of their almost 60 percent market share, as fewer and fewer people took to public transportation (http://jakartaglobe.id/commentary/fixing-indonesias-publictransport-woes, accessed on 14 June 2016). This growth was and still is not concurrently carried out with enough responsibility from the citizens. Vehicle ownership symbolizes prestige and relates to socioeconomic status, while quantity is valued over quality: the more vehicles one owns the better their perceived economic status. Gridlock, terrorist threats, accident, and inconvenient public transport systems are becoming a hindrance to productivity and a winning strategy to increase citizens' stress levels.

As road users, we may have at times put ourselves at very high risk. Road fatalities and injuries, which have become severe problems. Globally, the World Health Organization (WHO) estimates that 1,25 million people die on roads every year, mostly occurring in developing countries, becoming the ninth leading cause of death. If no action is taken, the WHO predicts that road traffic fatalities will become the seventh leading cause of death by 2030 (www.who.int/gho/road_safety/mortality, accessed on 25 Agustus June 2016). Traffic fatalities and injuries have cost Indonesia 2.9 percent of its total gross domestic product (GDP), as estimated by the Asian Development Bank (ADB). Hence 
traffic safety, which has not received much attention to date, must be prioritized in the planning and evaluation of transportation-related projects.

Similar to this, the EMBARQ WRI data in 2011 also indicated that caroriented cities like Jakarta and Atlanta had fatality rates of 6.4 and 9.7 per 100,000 inhabitants respectively, higher than a transit-oriented city such as Tokyo with a fatality rate of 1.3 per 100,000 inhabitants (www.wrirosscities.org, accessed on 20 July 2016).

As road users, we may have at times put ourselves at very high risk. Road fatalities and injuries, which have become severe problems over the last decades, continue to haunt road users, especially pedestrians (Retno Wihanesta and Nirarta Samadhi, the jakartapost, 22 November 2016).

Beside accident the public road transportation, terrorist attact is also concerned as well. Terrorist attact against public road transportation have been raising in the last decades. Still fresh in everyone's minds are the thwarted assault abroad the Brussels-Paris train in August 2015, the horrific November 2015 attact in Paris and subscuent terrorist plts against transportation targets in Europe. In addition, the tenth anniversary of the deadly July 7, 2005 terrorist attack on London Transport was marked this past summer.

Terrorist attact against public transport and public areas are an appropriate time to ask serious questions about the long-term trends in terrorist and serious criminal attact against public surface transportation in the world.

The number of attacts trends upward from the 1970s to around the turn of the $21 \mathrm{st}$ century. Spain reaches a high point in 2001, with 17 attacts. The United Kingdom reaches its high point in 1992, with eight attacts, and France in 1995, and Germany in 2003, each with five attacts. Around 2001, when the total number of attacts reaches a hig of 27 , the peaks begin to decline but generally remain above the high points of the 1970s and 1980s (Bruce R. Butterworth, a Mineta Research Associate, 2015: 15). 
Overall, since 1070, terrorist have attacked trains, public areas, and rail station more frecuently than they have attacked buses. Attacks on both target categories have increased, although at a higher rate for bus targets: 232 attacks have targeted passengers trains and subways; 126 attacks were carried out against scheduled buses, and three attacks targeted passengers ferries, and terminals. The deadliest incidents, however, occured in enclosed environments: subways trains and underground subway stations, and enclosed surface train stations. Although there were only $46(13 \%)$ of the 361 attacks in these enclosed environments, they account for $345(71 \%)$ of the 485 fatalities and $2.958(72 \%)$ of the 4.125 injuries.

Terrorism can be defined as a phenomenon which is existing from the beginning of human history. In the International and Hungarian literature the development of the so caleed moderns-age terrorism was onto the scientific articles in the years of 1960s at the end of the past century and mainly linked to the airplane hijacks. The statement that the traffic is one of those areas that can be wounded easily in war is a frequenly used expression, as the traffic's service and operating features demand high infrastructural and device requirements. Because of the same features we can enumerate the elements of the traffic system in peacetime onto the catastrophe-sensitive areas. The effects of the potential catstrophe situation or a terrorist attact may not only come locally, but in a midshort term may disable the traffic on regional level, a bigger part of country or all of the country. A provisional failing out of the traffic network due to damages may hinder the continous maintenance of the international traffic purely due to geographycal reasons (Horvath, 2006). The vulnerability of the traffic system includes the following factors (Mineta Transportation Institute, January 25, 2016):

a. The big numbers of transport terminals of persons and goods;

b. The lenght of the traffic lines and its sensitivity for destroying; 
c. Frozing of the traffic control systems;

d. The high number of vehicles and their movements;

Indonesia as a state respecting human rights in line with Indonesian constitution, so state (government) should have concerned safety of passengers or users using a public road transportation and public areas. In line with Article 28 A of Indonesian Constitution states that Every person shall have the right to live and to defend his/her life and existence. Article $28 \mathrm{G}$ of Indonesian Constitution also state that (1) Every person shall have the right to protection of his/her, family, honour, dignity, and property, and shall have the right to feel secure against and receive protection from the threat or fear to do or not do something that is a human right;(2) Every person shall have the right to be free from torture or inhumane and degrading treatment, and shall have the right to obtain political asylum from another country.

Briefly on the derivative rules, in line with Indonesian Law number 22 of 2009 on Traffic and Public Road Transportation, related to the safety protection, it only concerns on the goodness of the road of public road transportation, such as road feasibility of vehicles, machines feasibility, and any technique requirement of vehicle, whereas public areas supproting public road transportation, such as bus station, halte, and rail station, is not still concerned by government.

In line with Indonesian Law Number 23 of 2007 on Train, safety protection affairs of passengers still do not concern on the preventive measures of terrorism crime and circumgyration of the narcoticss crime. This issue is important to be observed because two cities are prone to be attacked by terrorist and sometimes passengers or visitors are not responsive to disasters as long as they are on public road transportation and its public areas. 


\section{B. PROBLEM STATEMENT}

According to the above problems, This article have two important problems to be observed, first problem is how already passengers or visitors of public road transportation and its public areas understand safety procedures of those areas?; second problem is how policy of safety protection need to be enforced on two public road transportation and public areas in order to protect right to life safely of passengers or customers?

\section{RESEARCH METHOD}

Type of this research is prescriptive legal research Normative and empirical legal research are used to this research which apply secondary data consisting of primary, secondary, and tertiary material law as well as using interviews and field observation to get data.All legal materials obtained in the study were collected, grouped according to their respective variables, to be further analyzed qualitatively.

\section{RESEARCH RESULT AND DISCUSSION}

I. Research Result

Authors distributed quitionnaries to passengers, quitionnaries ask to passengers about safety and security procedures. There are many safety procedures consisting of evacuation route, extinguisher cites, health workers, security workers, terrorist attacks, threat of theft of goods, and safety procedures in train.

Tabel 1. Data source obtained by interview and distributing quitionnaires

\begin{tabular}{|c|c|c|c|}
\hline No & Research Sites & District & Data Source \\
\hline 1 & $\begin{array}{c}\text { Solo Balapan Rail } \\
\text { Station }\end{array}$ & SURAKARTA & Station Head \\
\hline 2 & Tirtonadi Bus Station & SURAKARTA & $\begin{array}{c}\text { Public Relation of Tirtonadi } \\
\text { Bus Station }\end{array}$ \\
\hline 3 & Tugu Station & YOGYAKARTA & \begin{tabular}{c} 
Station Head \\
\hline 4
\end{tabular} \\
\hline
\end{tabular}




\section{a. Solo Balapan Railstation}

\section{a.1.passenger}

Researcher distributed quitionnaries to tweenty passengers, data obtained explaining that only approximately eleven passengers understand safety and security procedures, and nine passengers in Solo Balapan railstation did not understand about safety and security procedures. Passengers are not responsive to any threats which can impact to them. Ten passengers believe that they will be able to face terrorist attacks and narcotics crimes inside but did not know what they have to do to prevent its crime, and ten passengers believe no terrorist attacks and no narcoticss crimes in Tugu railstation.

\section{a.2. Head of Solo Balapan Rail Station}

Based on the interview with Mr. Budi as Head of Solo Balapan Station, In order to meet the existence of Asean Economic Community (MEA) from the Station itself has prepared various strategies, including the existence of a plan for the manufacture of KRL (Railway Electric); To modernize the point of mechanical to electric; Improving services for the community, both passengers and visitors; There is an increase in cooperation with outsiders for the sale of train tickets, now there is also an E-Kios facility to make direct ticket purchases for 24 hours.

Otherwise there are still many obstacles faced by Solo Balapan Station itself in running its operations, barriers and solutions are among the first is the limited fleet of trains, especially during "weekend" where there is an increase in the number of Train passengers, the solution to handle the problem in addition to optimizing the fleet or Train carriage, usually the Solo Balapan Station will operate the Outbreak (Train Extraordinary) which can only run for once a week, ie on the day of the weekend. Secondly, that is the lack of human resources that blended, currently the human resources at Solo Balapan Station are mostly high school graduates, but the solution that can be done is to do the equation of diploma become S-1. Third, the lack of sufficient parking space, but it is immediately overcome by the construction of parking space beside Solo Station Balapan. Another obstacle is there is still no body checker and metal detector to prevent terrorist attacks and cyrcumgyration of narcoticss 


\section{b. Tugu Station}

b.1.passengers

Researcher distributed quitionnaries to thirty passengers, data obtained explaining that only approximately ten passengers understand safety and security procedures, and twenty passengers in Tugu railstation did not understand about safety and security procedures. Passengers are not responsive to any threats which can impact for them. Ten passengers believe that they will be able to face terrorist attacks and narcotics crimes inside but did not know what they have to do to prevent its crime, and twenty passengers believe no terrorist attacks and no narcotics crimes in Tugu railstation.

\section{b.2. Head of Tugu RailStation}

According to Head of Tugu Rail Station, Nurul Aris Diantoro, There are many aspects of safety and security applied for a long time in the Standart Operating System of Tugu Rail Station. Those aspects are right which have to be gotten inside by passengers.

The Supporting fasilites and infrastructures of safety and security provided by Tugu's Official Officer as well, such as A special toilet for people with dissabilities, a special route for people with dissabilities when they will board on train, high fence boundaries zone have been assembled so that prospective passengers who want to wait for the train will be save as well, a evacuation route, a gathering point, extinguishers, cardiac tool provided by a health worker for fainted passenger, collaps, coronary people, prohibition for carrying a sharp weapon. Tugu Station also has a task force or special team to handle emergencies, which consists of station officials and coordination team in evacuating visitors in case of emergency disaster, fire, earthquake, terrorism. Yet, there are still no metal detector and body checker (passengers screening) to prevent terrorist attack and narcotics cyrcumgyration

\section{c. Tirtonadi Bus Station}

\section{c.1.Passenger}

Researcher distributed quitionnaries to twenty passengers, data obtained explaining that only approximately nine passengers understand safety and security procedures, and eleven passengers in Tirtonadi station did not understand 
about safety and security procedures. Passengers are not responsive to any threats which can impact to them. They believe no terrorist attacks and no narcotics crimes in inside.

\section{c.2. Head of Tirtonadi Bus Station (Nurul Aris Diantoro)}

According to the public relation of Tirtonadi Bus station, The visitor's right to safety and security at Tirtonadi Bus Station is necessary and must be met. Terminal Tirtonadi is adopting the concept of terminals located in Singapore so as to ensure the safety and security of visitors, Tirtonadi provides Bus Priority. Where there are downs and rises of individual visitors, comfortable waiting rooms, clean and safe, and equipped by CCTV in every corner. He argued passengers have understood about safety and security standart tools generally because Tirtonadi's officers have socialized by safety clues attached on the bus station's wall. However, passengers are not responsive to the clues attached.

Visitor screening in preventing terrorist and narcoticss crime will be planed by Tirtonadi's officer, such as metal detector and body checker because station head of Tirtonadi has an ambition to create the pilot terminal, however there will be many barriers, no support government, in the implementation.

\section{Terror Threat Against Transport Infrastructure,}

Road and urban public transport terminals, station, and transshipment centres were mainly established at the meeting points of different traffic lines. According to the history and operational experiences on mdern-age focusing on passenger transport, than against the transport of goods. If we compare the terror-threat against infrastructure, building, and vehicles, than we can see that much more terrorist attacks were directed against the vehicles, than against bridges or tunnels. Targets can be grouped based on its geographical areas. In bigger cities more terror actions are targeted against a traffic objects than in the rural areas (Horvath, 2006). Public transport is a popular target of terror groups. After September 11, 2001. We can find increasing number of cases, that could create great publicity. Just some examples: terrorist attacks against the Moscow underground, Madrid suburban train service, London public transport and suburban train service in Mumbai (Attila Horvath, Characteristics of Terror Threat in Goods Transportation, AARMS Journal, Vol. 8, No. 2 (2009), page 4). 
After the attacks against World Trade Centre on September 11, 2001, British experts expected a similar attack against Great Britain. Most of them agreed that London will be one of the potential coming targets and the attack will be most probably against the London underground network. It was an organizational mistake by terrorists that the explosion happened not in the underground but in a doubledecker bus. This trrorist attack against London showed also asymetric character of terrorism. According to official statement there were four crminal who organized at least 51 terror cases that required at least 6.000 pounds financial power (Intelligence and Security Committee, Report, 2006). The Assassination and explosion series in London were executed within two weeks are calling our attention on that terrorist today are capable to repear their large - scale terrorist attacks in a metropolis within a short period of time. This has to be evaluated as anovelty and cumulative danger of the modern - age terrorism.

Terrorist crime on public transport is tackled in a number of different ways. The Mayor argues that the reduction of crime on public transport is as a result of continoued investment in policing and the use of effective problem solving and innovative tactics. High visibility patrols, joint problem solving activity, and reactive investigation of offences were cited to us as key.

It is recognised that there will be future challenges, and that more will be needed that just new policing skills. Resources need to focus on more advanced crime reduction, problem solving and engagement activity, stopping crime and managing offenders, and the use of innovative equipment, such as body-worn cameras, enhanced CCTV coverage and handheld mobile devices (Joanne McCartney AM, 2016, Crime on Public Transport, .London Assembly, page 5)

\section{Drug Use}

It is estimated that, globally, in 2012 some 243 million people corresponding to some 5,2 per cent of the world population aged 15-64 has used an illicit drug-maily a substance belonging to the cannabis, opioid, cocaine or amphetamine, at least once in the previous year. 
Unsafe injecting drug use can have very serious health implications due to the high risk of the transmission of blood-borne infections such as HIV, as well as hepatitis B and hepatitis C, contracted by sharing of contaminated injecting equipment. The joint United Nations Programme on HIV/AIDS reports that the number of new cases of HIV among people who inject drugs remains high, constituting up to 40 per cent of new infections in some countries and resulting in a major public health challenge (UNAIDS, 2013, Global Report: UNAIDS Report on the Global AIDS Epidemic, Geneva). A recent study on the global burden of disease from drug dependence estimated that in 2020, 1. 980.000 years of life were lost in conjunction with unsafe injecting drug use, through premature death as a consequence of HIV infection, and a further 494.000 years of life were lost worldwide due to hepatitis C infection (L. Degenhard and others, Global burden of disease attributable to illicit drug use and dependence: findings from the Global Burden of Disease Study 2010, The Lancet, vol. 382, No. 9904 (29 August 2013), page. 156)..

According to expatfocus: "Indonesia has extremely harsh punishments for drug offenses - visitors are greeted with cheery "death to drug traffickers" signs at airports and recent cases have seen long jail terms for simple possession — but drugs are still widely available. By far the most common is marijuana (known as gele or cimeng), which is not only sold to tourists but is used as food in some parts of the country, notably Aceh. Magic mushrooms are advertised openly in parts of Bali and Lombok, and hard drugs are common in the Jakarta nightlife scene. Still, it's highly advisable to steer well clear or, at very least, be very discreet as entrapment and drug busts are common and you really, really don't want to get involved with the Indonesian justice system; thanks to the anti-corruption drive, you cannot even count on being able to bribe your way out anymore."

Due to an increase in drug trafficking activities throughout Indonesia in 2011, the INP and National Narcotics Board (BNN) continued to seize large quantities of crystal methamphetamine (known locally as shabu). In addition, authorities discovered several clandestine methamphetamine laboratories capable of producing large quantities of this dangerous drug. Indonesian Customs, INP, and BNN stationed at the air and seaports of major cities such as Jakarta, Surabaya, Bali, and Medan continue to arrest drug couriers from many nations. Further investigation of many of these smuggling attempts has revealed that Indonesia has become a primary destination for drugs smuggling operations controlled by Iranian and West-African 
drug trafficking organizations. In addition to large volumes of methamphetamine, law enforcement officials have seen an increase in heroin seizures and also have seized large volumes of synthetic drugs including ecstasy and ketamine. The demand for illegal drugs in Indonesia, with a growing population in already-over-crowded cities, remains high. As a result, INP and BNN continue to coordinate with other foreign and domestic law enforcement agencies to stem the steady flow of illegal drugs into Indonesia. [Source: Indonesia 2012 Crime and Safety Report U.S. Department of State, Overseas Security Advisory Council (OSAC)].

\section{Human Rights of The Passengers (Health and Safety on Train)}

Common rules should have been drawn up in an effort to ensure that passengers receive at least a minimum level of assistance in the event of serious threats or getting bout (disease attack) of their journey, irrespective of the mode of transport used, and, in particular, to protect more vulnerable travellers. The rules also provide for compensation schemes. A wide range of derogations may be granted for rail and road transport services, however, and court actions challenging the application of the rules are still common. The construction of the health fasilities is very important for the passengers. It is an implementation of the Indonesia Constitution of 1945 as well, especially for article 28A stating that everyperson has the right to life and maintain his/her life, and Article $28 \mathrm{H}$ stating that everyperson has the right to health. The passengers (travellers) have the right to life safely and the right to health as long as they are getting their journey. But, There are still many public areas related public road transportation which have not provided or constructed the health facilities for them yet.

The number of passengers boarding a train can exceed the seats available. This can be caused by the "turn-up and go" nature of Indonesian's domestic railways, the increasing popularity of rail travel and increased advanced ticket booking leaving fewer seats for othertravellers. We recognise that crowding can be uncomfortable and sometimes might make passengers feel unsafe, but we doubt that manu passengers would accept restrictions on their ability to board a train of their choice.

At this time, Indonesia's railways have a good and improvinf safety record and train accidents are increasingly rare, but it is inevitable that on heavily loaded a train, there are more passengers at rist of an injury in the event of a train accident. This does not necessarily mean that an individual passenger is at greater risk. 
As the health and safety authority for Indonesia's railway, PT KAI shoul have responsibility for ensuring railway companies protect passengers from any health and safety risk caused by crowded trains, so far as is reasonable practicable.

Researchers compared with the Britain's railways on the protection of health and safety for passenger as the following measures:

a. Our aims

1. To take passengers "health and safety concerns about crowded trains seriously and respond appropriately in line with our risk based priorities and enforcement policy statement (Office of Rail Regulation, 2015, ORR's health and safety Policy Position on Train Crowding, page 2);

2. To ensure train operators fulfill their health and safety responsibility to protect passengers "helath and safety", so far as is reasonably practicable; and

3. To use our influence, where we can, to hel make sure that processes to identify, reduce and alleviate crowding are operated efficiently and effectively;

b. Position

1. Trains are designed, to operate safely, even when many passengers are standing, for example, by the provision of handholds; and

2. There is no conclusive evidence linking overcrowding with anything other than low level helath and safety risks to individual pasengers.

c. Train Operators

1. To comply with their health and safety responsibilities and protect, passengers from risk on crowded trains, so far as is reasonbly practicable;

2. To apply recognised good practice to manage on-train crowding, such as the rail safety and standarts board's "Crowd management on trains: a good practice guide" provides useful guidance (www.rssb.co.uk/research-development-and-innovation research-and development-catalogue/pb009693, accessed on 08 May 2016). This includes a customer-focused approach which listens to feedback from its front-line staff, provides timely information to passengers, reminds 
passengers to store their luggage safely, and has contingency plans to reduce risks from service disruption;

3. To ensure their staff are trained and competent to manage the risks from: emergency evacuation, crowding on platforms and station, which can make train crowding worse, luggage and bycicles blocking aisles and exits, and travelling on underground routes in hot weather, and in particular when trains breakdown or service is disrupted.

d. Passengers can help

1. We recognise passenger can play an important role in helping to reduce the risks from crowding, for example by: avoiding blocking entrances and exits, stowing luggage safely, particularly on crowded trains, carrying a bottle of dringking water during hot weather, and using information about busy train services provided by train opertaors to help plan journeys.

\section{Safety and Security Desaign of Public Areas}

Public areas supporting public road transportation may be defined as open space that is freely accessible, where each individual or group can perform various activities (Carr, 1992: 55). Good public spaces serve as centers, where various social, economic, and cultural exchange activities occur. A public space can be said to succeed when the physical space and environment support each other's diversity of functions and daily activities. The controversy over the relationship between crime and spatial design began to grow. The question is how can we achieve a lower crime rate with sustainable urban design. There are two opposing theoretical pairs to solve this, known as encounters and enclosures.

Encounter models advocate open space and are freely accessible to locals and foreigners. Here, foreigners are viewed as the subject of security supporters (as a postitive element) who oversees the space. Jane Jacobs observes that mixed-use traditional patterns of roads are better than land-use separations for single-use functions such as centralized housing, centralized health, retail and so on. He describes the ideal condition of a public 
space design in relation to security, including a clear boundary between public and private areas, and the presence of natural controls (eyes on the street). He also added two ideal conditions, namely the combination of age and social class and the continuous use of public space at all times, which is in fact difficult to achieve (Jane Jacobs, 1961 ). This model explains that free open space is more secure because it serves as a place of social interaction so that indirectly also increases the awareness and activity in the public space.

Enclosure model recommends closed spaces and non-free (limited) environments. Foreigners are perceived as a threat / danger. This model was pioneered by Oscar Newman (1972) in the defensible place concept, with four major design elements, yaituterritoriality, surveillance, building image, and juxtaposition of residential with other facilities. This model explains that an environment with closed access (separating strangers) can reduce the intention / opportunity to commit criminal acts indirectly.

Security and Safety are two different things. Security is a perception of protection from harm, while safety is the real protection of danger. Thus, safety desaign should be more focused. This leads us to the theory of Jane Jacobs offering a solution to the openness of public space, where foreigners act as 'watchdogs' (Marcuse, 2006).

Encounter and enclosure models are two urban design solutions that can be adapted according to specific conditions. By proper public space design, hazards can be anticipated more effectively. Public spaces should be designed in the context of a city holistically, not individually. The public space must have a good space organization, so as to reduce the crime rate in this case.

1. The Safey and Security System of Public Areas

a. Visitor Management System 
The Visitor Management System is a system used to perform guest or visitor management, applied usually to high rise buildings, offices, public agencies or governments whose primary function is to reduce unwanted risks, including criminal elements, terrorism, and actions Other negative (http://ibnur95.blogspot.co.id/2015/03/makalah-utilitas-sistem-keamanan-gedung).

Nowadays, the Visitor Management System is a great way to prevent unwanted things, placed in portions to help the security and security systems of a preexisting agency, but not to replace existing ones.

This form of Visitor Management System is very flexible to adapt to the situation and condition with your agency, starting with only a single independent system, up to a very wide system and integrated with current technological advances, whether it be internet or intranet, face recognition, biometrics, and so forth.

\section{b. Access Control}

An Access Control security system allows building owners and property to do more than just control entry to a protected area. It can also create electronic history or information about anyone entering a protected room. This information recapitulation helps business owners identify who comes into the room at certain times. There are several methods of verification on the Access Control system which is suitable for use, and it is an option for those of you who want a security system like what you need in accordance with the needs and budget you have of course (Nemeth, 2010: 50).

\section{c. CCTV (Closed Circuit Television)}

CCTV (Closed Circuit Television) is the use of video cameras to transmit video signals to specific places, within multiple sets of monitors. Unlike television broadcasts, CCTV signals are not openly transmitted. CCTV is mostly used for 
surveillance in areas which require monitoring such as banks, warehouses, public places, and homes left by their owners.

\section{E. CLOSING}

The number of passengers boarding a train can exceed the seats available. This can be caused by the "turn-up and go" nature of Indonesian's domestic railways, the increasing popularity of rail travel and increased advanced ticket booking leaving fewer seats for othertravellers. We recognise that crowding can be uncomfortable and sometimes might make passengers feel unsafe, but we doubt that manu passengers would accept restrictions on their ability to board a train of their choice.

Common rules should have been drawn up in an effort to ensure that passengers receive at least a minimum level of assistance in the event of serious threats or getting bout (disease attack) of their journey, irrespective of the mode of transport used, and, in particular, to protect more vulnerable travellers. The rules also provide for compensation schemes. A wide range of derogations may be granted for rail and road transport services, however, and court actions challenging the application of the rules are still common. The construction of the health fasilities is very important for the passengers. It is an implementation of the Indonesia Constitution of 1945 as well, especially for article 28A stating that everyperson has the right to life and maintain his/her life, and Article $28 \mathrm{H}$ stating that everyperson has the right to health. The passengers (travellers) have the right to life safely and the right to health as long as they are getting their journey. Security officers should check the condition of bags and luggage of passengers or visitors in order to prevent any threats there. Safety briefing is also implemented to keep a passengers concer.

There are many kinds of measures to protect the passengers boarding train or bus. The protection of the passengers getting their journey is necessary to be implemented, this is due to Indonesia public areas often targeted by terrorist attacks or to prevent the spread of drugs (narcotics). Those measures are as follows:

a) The Visitor Management System is a system used to perform guest or visitor management, applied usually to high rise buildings, offices, public agencies or governments whose primary function is to reduce unwanted risks, including criminal elements, terrorism, and actions Other negative This form of Visitor Management System is very flexible to adapt to the situation and condition with 
your agency, starting with only a single independent system, up to a very wide system and integrated with current technological advances, whether it be internet or intranet, face recognition, biometrics, and so forth.

b)

\section{Access Control}

An Access Control security system allows building owners and property to do more than just control entry to a protected area. It can also create electronic history or information about anyone entering a protected room. This information recapitulation helps business owners identify who comes into the room at certain times. There are several methods of verification on the Access Control system which is suitable for use, and it is an option for those of you who want a security system like what you need in accordance with the needs and budget you have of course.

c)

\section{CCTV (Closed Circuit Television)}

CCTV (Closed Circuit Television) is the use of video cameras to transmit video signals to specific places, within multiple sets of monitors. Unlike television broadcasts, CCTV signals are not openly transmitted. CCTV is mostly used for surveillance in areas which require monitoring such as banks, warehouses, public places, and homes left by their owners.

\section{BIBLIOGRAPHY:}

\section{Books:}

Bruce R. Butterworth. 2015. Transportation Safety and Security Cente. Mineta Research Associate

Carr, S., et al. 1992. Public Space. Cambridge: Cambridge University Press. Colquhoun, I. (2004). Design Out Crime: Creating Safe and Sustainable Communities. Oxford: Architectural Press.

Jacobs. J. 1993. The Death and Life of Great American City. New York: Random House, Inc. Joanne McCartney AM, 2016, Crime on Public Transport, .London Assembly

Marcuse, P. 2006. Security or Safety in Cities? The Threat of Terrorism after 9/11. International Journal of Urban and Regional Research. 
Nemeth, J. \& Hollander, J. 2010. Security Zones and New York City's Shrinking Public Space. International Journal of Urban Design.

UNAIDS, 2013, Global Report: UNAIDS Report on the Global AIDS Epidemic, Geneva

\section{Journals:}

Attila Horvath, Characteristics of Terror Threat in Goods Transportation, AARMS Journal, Vol. 8, No. 2 (2009)

L. Degenhard and others, Global burden of disease attributable to illicit drug use and dependence: findings from the Global Burden of Disease Study 2010, The Lancet, vol. 382, No. 9904 (29 August 2013

\section{Internet:}

http://jakartaglobe.id/commentary/fixing-indonesias-public-transport-woes, accessed on 14 June 2016

www.wrirosscities.org, accessed on 20 July 2016

Retno Wihanesta and Nirarta Samadhi, the jakartapost, 22 November 2016

www.rssb.co.uk/research-development-and-innovation research-and -developmentcatalogue/pb009693, accessed on 08 May 2016

http://ibnur95.blogspot.co.id/2015/03/makalah-utilitas-sistem-keamanan-gedung

\section{Interview:}

\begin{tabular}{|c|c|c|c|}
\hline No & Research Sites & District & Data Source \\
\hline 1 & $\begin{array}{c}\text { Solo Balapan Rail } \\
\text { Station }\end{array}$ & Surakarta & Station Head \\
\hline 2 & Tirtonadi Bus Station & Surakarta & $\begin{array}{c}\text { Public Relation of Tirtonadi } \\
\text { Bus Station }\end{array}$ \\
\hline 3 & Tugu Station & Yogyakarta & Station Head \\
\hline 4 & $\begin{array}{c}\text { PT.KAI (Operational } \\
\text { Region IV) }\end{array}$ & $\begin{array}{c}\text { Public Relation of The } \\
\text { Operational Region of PT KAI }\end{array}$ \\
\hline
\end{tabular}


